\title{
Morphological Variation and Occurrence of Persistent Metopic Suture in Indian Population
}

\author{
Sabita Singh ${ }^{1}$, Parineeta Suman ${ }^{2}$, Arun Kumar Panigrahi ${ }^{3}$ \\ ${ }^{1}$ Associate Professor, ${ }^{2}$ Assistant Professor, Department of Anatomy, Velammal Medical College Hospital \\ \& Research Institute, Madurai, Tamilnadu- 625009. \\ ${ }^{3}$ Consultant, Arvind Eye Hospital, Madurai, Tamilnadu-625020.
}

\begin{abstract}
Introduction: The metopic suture is a dentate-type suture between two frontal bones extending from the nasion to the bregma. The complete metopic sutures extend from nasiontobregma, whereas incomplete metopic suture occupies a small area between these two points. Incidence of metopism can be from $1 \%$ to $12 \%$, and it is slightly more prevalent among male.
\end{abstract}

Aim: To describe the different types of metopic suture and the rate of occurrence of each type in Indian population.

Materials and methods: 80 (48 male and 28 female) adult human dry skulls were differentiated into different sex and macroscopically examined for metopic suture.

Results: Out of the 80 skulls examined, the metopic suture (complete- 2 \& incomplete-9) was found in $13.75 \%(11 / 80)$ of the skulls, of which $18.75 \%$ (9/48) were in males and $6.25 \%(2 / 32)$ in females.

Conclusion: The knowledge of morphology of metopic suture can alert the neurosurgeon, imaging persons and forensic persons for the interpretation of skull X-rays and medicolegal autopsies.

Key Words: Metopic suture, Metopism, Frontal bone, Morphology, Racial variation.

\section{INTRODUCTION:}

$\mathrm{T}$ The knowledge of the morphology of the metopic suture is important due to its increasing significance in field of modern Medicine and Surgery. The metopic suture is a dentate-type suture between two frontal bones extending from the nasion to the bregma. ${ }^{1}$ The frontal bone is a unpaired, median and symmetrical bone that occupies the most anterior part of the cranium forming the forehead which is a common area for scalp \& face. It joins with the parietal, ethmoid, sphenoid, nasal, zygomatic, lacrimal, and maxillary bones, thereby contributing towards uniting the neurocranium and the viscerocranium. ${ }^{2}$ The human frontal bones begin to ossify in the mesenchyme via two ossification centers at approximately eight weeks gestation which appears near frontal tuber. At birth the two halves of frontal bone remain separate by the metopic suture which is replaced by bone at about 2 years .The term metopic is from Greek meaning "in the middle of the face".,

The fusion of the metopic suture normally begins at the nasion proceeding superiorly and terminates at the anterior fontanelle. ${ }^{5}$ But it was also described that the obliteration of metopic sutures beginsat the level of frontal tuber and extends in both the direction. Sometimes traces of metopic suture found either at the bregma or nasion in case of incomplete fusion. ${ }^{6}$ The complete metopic sutures extend from nasiontobregma, the condition is called as metopism. ${ }^{7}$ If the sutureis not present 
throughout and occupies a small area between these two points, they are considered as incomplete metopicsutures. They are also called as median frontal sutures and usually present between the two superciliary arches. ${ }^{8}$

There are divergences in the different studies regarding the time of closure of the metopic suture. Metopic suture starts fusing at the age of two years and may have completely fused by the age of seven years. ${ }^{9,10}$ Bademci $G$ et al reported that the time of physiological closure of these sutures varies from birth to 8 years of age, the widely accepted closing period has been approximated at 2 years of age. ${ }^{11}$ However, in approximately $8 \%$ of adults, the two halves of the frontal bone do not fuse and the metopic suture persists. ${ }^{5}$ Metopism has various degree of incidence in different races. Their incidence was $7-8 \%$ in Europeans, $1 \%$ in Africans and $4-5 \%$ in Mongolian population. Overall, the range of incidence can go from $1 \%$ to $12 \%$, and it is slightly more prevalent among males. ${ }^{12}$ Manyauthors also reported that there exists a geographical variation among the incidence of metopic sutures. In Lebanonit was $0.82 \%, 13$ in Nigeria 3.14\%, 9 in India 2.66\%, 14 and in Europe 7 to $10 \% \cdot{ }^{12,15}$ These sutures may be misdiagnosed as vertical traumatic skull fractures extending in the mid-line in head injury patients. ${ }^{11}$ In the present study, the objectives were to determine the different types of metopic suture and its rate of occurrence in Indian population.

\section{MATERIALS AND METHODS :}

This is a descriptive study which was conducted on 80 (48 male and 28 female) adult human dry skulls obtained from department of Anatomy Velammal Medical College, Madurai. Malformed and fractured skulls were excluded from the present study. The skulls were differentiated into males and females based on the criteria of sexual dimorphism.
All the skulls were macroscopically examined and inspected carefully at normafrontalis for the presence or absence of the metopic suture. The method of classification of the metopic sutures is done based on the earlier studies on metopic suture. ${ }^{13,14}$ It was considered to be complete when it continued uninterruptedly from the nasion to the bregma. If it extends to a smaller distance either from the bregma or from the nasion, it is termed as incomplete type. The specimens were photographed and the findings were carefully observed and noted. The frequency of complete and incomplete metopicsutures were calculated. The results obtained were compared with that of other studies.

\section{RESULTS:}

Out of the 80 skull, examined, the metopic suture (complete \& incomplete) was found in $13.75 \%$ $(11 / 80)$ of the skull, of which $18.75 \%(9 / 48)$ were in males and $6.25 \%(2 / 32)$ in females.(Table 1$)$.

A complete metopic suture was found in 2 skull (2.5\%), while an incomplete suture was observed in 9 skull (11.25\%) (Figure 1\&2).

\section{Figure 1. Skull showing complete metopic suture}

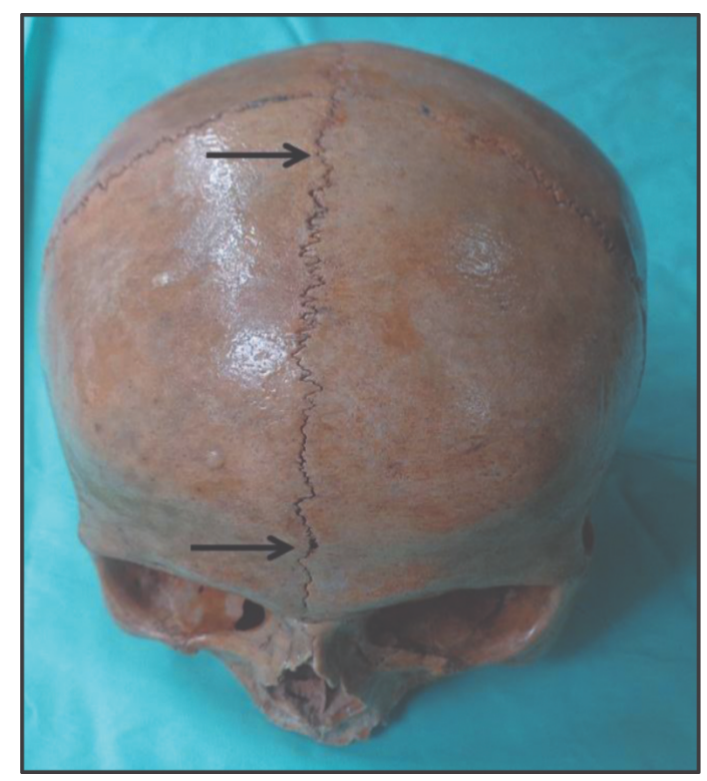




\section{Figure 2: Skulls showing different types of incomplete metopic suture}

a) Linear type (arrow) b) 'V' shape

c) Double type (*) d) Absent metopic suture

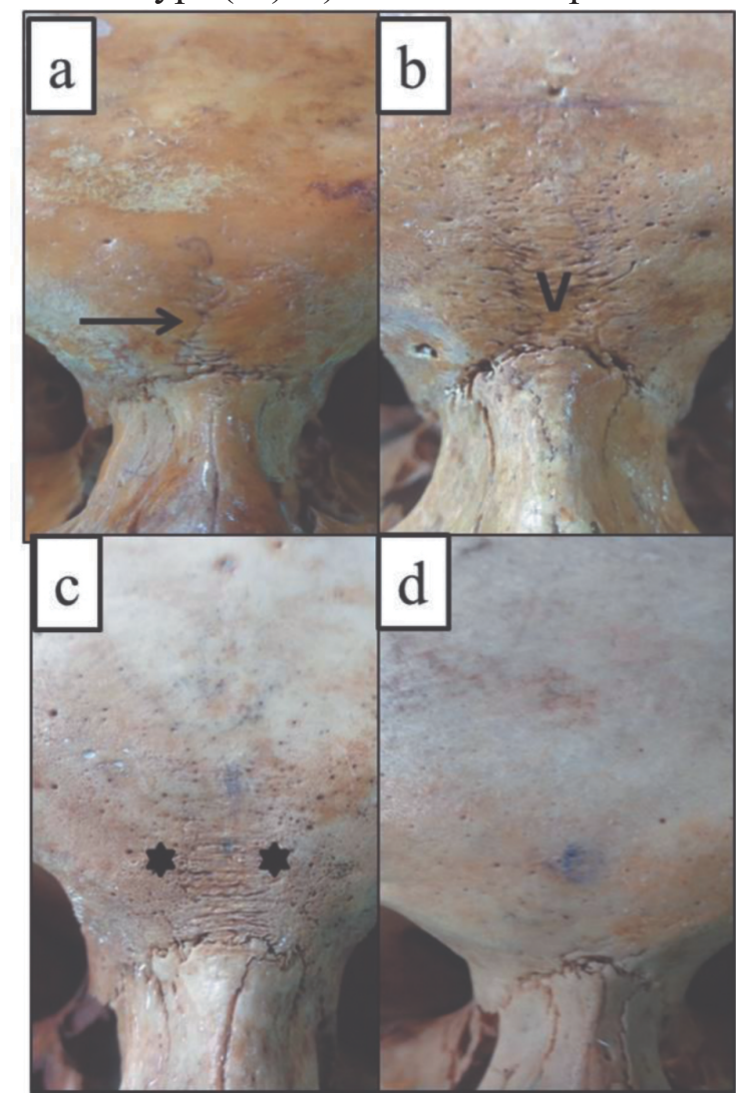

Among the incomplete ones, $5(6.25 \%)$ were linear (Figure 2a), 1 (1.25\%) was ' $\mathrm{V}$ ' shaped (Figure 2b) and 3 skulls $(3.75 \%)$ had double metopic (Figure 2 c) sutures (Table 1). The remaining $86.25 \%$ of the skulls did not have metopic suture (Figure 1d).The frequency, number of complete and each incomplete metopic suture shape with respect to gender is presented in Table 1. The results of present study compared with previous studies and the racial variability of the metopism is shown in Table 2.

Table 1. Occurrence of different types of metopic sutures with respect to sex

\begin{tabular}{|c|c|c|c}
\hline Shape & Male & Female & Total \\
\hline Complete & $2(4.16 \%)$ & Nil & $2(2.5 \%)$ \\
\hline Incomplete & $7(14.58 \%)$ & $2(6.25 \%)$ & $9(11.25 \%)$ \\
\hline Linear & $4(8.33 \%)$ & $1(3.12 \%)$ & $5(6.25 \%)$ \\
\hline V & $1(2.08 \%)$ & Nil & $1(1.25 \%)$ \\
\hline Double & $2(4.17 \%)$ & $1(3.13 \%)$ & $3(3.75 \%)$ \\
\hline
\end{tabular}

\section{DISCUSSION:}

Metopic suture is thought to be a normal variant of the cranial sutures. ${ }^{16}$ It forms from the lack of union of the two frontal bones during embryonic development.

Various theories have been proposed for the persistence ofmetopic suture. Metopism can be related to abnormal growth of the cranial bones, hydrocephalus, heredity, or atavism. ${ }^{17}$ Most of the scientists accepted the genetic factor as one of the current cause of metopism. ${ }^{18}$ Active expression of some of the cytokines during cranial fusion can be one of the causes. ${ }^{19}$ It was reported that the impaired closure of the metopic suture is common in Apertsyndrome. ${ }^{20}$ Levine $\mathrm{J}$ has mentioned that active resorption of the chondriodal tissue results in metopism. $^{21}$ Falk D et al suggested that the persistent metopic suture is an adaptation for giving birth to babies with larger brains, and is related to the shift to a rapidly growing brain after birth and even may be related to the expansion of the frontal lobes. ${ }^{17}$ It has been stated that the metopic sutures increase the width of the skull. ${ }^{22}$ But Jit and Banga reported that the cranial shape is not affected by persistence of metopic suture. ${ }^{23}$ Skrzat et al. suggested that it cannot be concluded that shape of skull affected by persistant metopic suture due to lack of suitable data. Although it is rare to find this suture in adults, its presence is not considered pathological. ${ }^{12}$ However, premature closure of any of the cranial sutures results in a pathology known as craniosynostosis and trigonocephaly and is termed as metopic synostosis. ${ }^{1,24}$

In the present study, the metopic sutures (complete and incomplete) were observed in $13.75 \%$ of the skulls which was higher than the study done in Indian population by Hemalata et al $(6.66 \%)^{25}$ but lower than that of Murlimanju et al $(64 \%)^{8}$ (figure $1,2)$. 
The incidence of metopic suture was reported between $7-10 \%$ among Scots, Mongoloids, and Europeans ${ }^{26}$.

The occurrence of metopic suture in male skulls were found to be more than in female skulls by Skrzat et al. ${ }^{12}$, Murlimanju et $\mathrm{al}^{8}$. In the present study also more number (9) of male skulls had metopic suture than female skull (Table1). However, it contradicts the findings of Castilho et al. ${ }^{28}$ who observed the female preporderance of metopic suture (female- $80 \%$, male- $20 \%)^{18}$. On the other hand Baaten et al reported the similar incidence of metopism in male and female?

In the present study, only twoskull (2.5\%) showed the complete metopic suture whereas the incomplete metopic sutures were found in nine skulls $(11.25 \%)$ (Table 1, figure1,2). The majority of skull showed incomplete metopic suture which was in accordance with the observations of Bilodiet al ${ }^{7}$ (complete-3.92\%, incomplete-7.84\%) Murlimanju et $\mathrm{al}^{8}$ (complete- $1.2 \%$, incomplete$63 \%$ ), Agarwal et $\mathrm{al}^{14}$ (complete-2.66\%, incomplete $38.17 \%$ ), Hemalata et al ${ }^{25}$ (complete$2.22 \%$, incomplete- $4.44 \%$ ) in Indian skull and Baaten et $\mathrm{al}^{9}$ (incomplete-.82\%, incomplete-.93\&) in Lebanese skull, Ajmani et $\mathrm{al}^{13}$ (complete-3.4\%, incomplete-31.57\% ) in Nigerian skull.

Different morphological types of incomplete suture had been found in various literatures. Incomplete metopic suture can be linear type, double type, 'V'shape, 'n' shape, 'H' shape or 'U'shape. ${ }^{8,13,14,27} \mathrm{We}$ observed maximum of linear type (6.27\%) followed by double type (3.75\%) and ' $\mathrm{V}$ ' type $(1.25 \%)$ (table 1, figure2). Other studies also reported linear type as common incomplete suture like Muralimanjuet $\mathrm{al}^{8}(22.2 \%)$ in Indian skull, Ajmani et $\mathrm{al}^{13}(24.27 \%)$ in Nigerian skull and Catilho $^{18}(69.57 \%)$ in Brazilian skull. But these studies showed much higher incidence than the present study. The other morphological types of incomplete metopic sutures like ' $n$ ' shape, 'H' shape and ' $U$ ' shape were reported by Ajmani et $\mathrm{al}^{13}$ Agarwal et $\mathrm{al}^{14}$ and del Sol et al ${ }^{27}$. But these types were not seen in present study. We found next common type of incomplete suture as double type (3.75\%) which is in contrast to the observation by Muralimanju et al ${ }^{8}$ (linear- 22.2\%, double type$19.7 \%)$.

The presence of a metopic suture is important clinically. Although the persistant metopic suture is rare anatomical variant, it must be included in the differential diagnosis of a suspected skull fracture particularly of the frontal bone.

Baaten et al. ${ }^{9}$ reported that the incomplete metopicsutures are difficult to identify on the $\mathrm{X}$ rays and may be mistaken for the vertical fractures close to the central line. Neurosurgeons have to be aware of the suture configurations to avoid confusion and unwanted dangerous offence in cranial surgery.

Table 2. Racial variation in the incidence of metopic suture as reported by various authors in their study

\begin{tabular}{|c|c|c|}
\hline Authors & Poulations & Frequencv rate \\
\hline Brvce et al (2017) ${ }^{[26]}$ & Australian & 1 \\
\hline & Mongolian & 5.10 \\
\hline $\begin{array}{c}\text { Frazer and Breathnach } \\
\text { et al (1965) }\end{array}$ & Scottish & 9.5 \\
\hline & Europian & $7-10$ \\
\hline Aimani (1983) & Eat Asian & $4-5$ \\
\hline Bilodi (2003) & Nigerian & $3-4$ \\
\hline Baaten et al. (2003) & Nepalese & 3.92 \\
\hline Casthilho et al (2006) & Lebanese & .82 \\
\hline Present studv (2017) & Brazilian & 7.4 \\
\hline
\end{tabular}

\section{CONCLUSION:}

The present study showed the different types of metopic suture and the wide variation in frequency of metopic suture in different races as well as in different geographical regions. The rate of 
occurrence of metopic suture was predominant in male. Moreover incomplete linear type metopic sutures were found to be more than that of complete type.

The knowledge of metopic suture can alert the neurosurgeon, imaging persons and forensic persons for the interpretation of skull X-rays and medicolegalautopsies. The present study can be not only a contribution to the scientific literature but can also be beneficial for the neurosurgeons and radiologists in their clinical practice.

\section{ACKNOWLEDGEMENT :}

We are thankful to all faculty members and Head of Department of Anatomy, Velammal Medical college Hospital \& Research Institute, Madurai for their extended cooperation. We are also thankful to previous authors, publishers, editors of all of those articles, journals and books from which we took our reference.

\section{REFERENCES :}

1. Bilgin S, Kantarc UH, Duymus M, Yildirim CH, Ercakmak B, Orman G, et al. Association between frontal sinus development and persistent metopic suture. Folia Morphol (Warsz). 2013; 72: 306-310.

2. M. Latarjet and A. R. Liard, "Cabec , a," in Anatomiahumana, M.Latariet and A. R. Liard, Eds., pp. 69-71, Panamericana, S̃aoPaulo, Brasil, 2nd edition, 1993.

3. Sahana SN. Human Anatomy. Vol I. 3rd edition, Howrrah: KK Publishers (P) Ltd. 1993: 462-469.

4. Guerram A, Le Minor JM, Renger S, Bierry G. "Brief communication: The size of the human frontal sinuses in adults presenting complete persistence of the metopic suture". American
Journal of Physical Anthropology. 2014; 154: 621-627.

5. K. L. Moore and A. F. Dalley, "Cabec , a," in Anatomia Orientada Para A Cl'1nica, K. L. Moore and A. F. Dalley, Eds., pp. 821-864, Guanabara Koogan, Rio de Janeiro, Brasil, 4th edition, 2007.

6. Romanes GJ: Cunningham Text Book of Anatomy, London:University Press, 1964:134

7. Bilodi AK, Agrawal BK, Mane S, Kumar A: A study of metopicsutures in human skulls. Kathmandu Univ Med J 2003; 2:96-99.

8. Murlımanju BV, Latha V Prabh, Mangala M. Pa, Avlyn Anisha Goveas et al.,.Median Frontal Sutures - Incidence, Morphology and Their Surgical, Radiological Importance. Turkish Neurosurgery. 2011;21(4): 489-493

9. Baaten PJ, Haddad M, Abi-Nader K, AbiGhosn A, Al-Kutoubi A, Jurjus AR. Incidence of metopism in the Lebanese population. Clin Anat. 2003; 16: 148-151.

10. Chaoui R, Levaillant JM, Benoit B, Faro C, Wegrzyn P, Nicolaides KH. Threedimensional sonographic description of the fetal frontal bones and metopic suture. Ultrasound in obstetrics \& gynecology. 2005; 26: 618-621.

11. Bademci G, Kendi T, Agalar F. Persistent metopic suturecan mimic the skull fractures in the emergency setting? Neurocirugia 2007; 18: 238-240.

12. Skrzat J, Walocha J, Zawilinski J. A note on the morphology of the metopic suture in the human skull. Folia Morphol 2004; 63:481-484. 
13. M. L. Ajmani, RK Mittal, and SP Jain.Incidence of the metopic suture in adult Nigerian skulls. Journal of Anatomy. 1983; 137(1): 177-183.

14. S. K. Agarwal, V. K. Malhotra, and S. P. Tewari. Incidence ofthe metopic suture in adult Indian crania. ActaAnatomica. 1979 ; 105(4) : 469-474.

15. Frazer JESand Breathnach AS.Frazer's Anatomy of the Human Skeleton, Churchill Ltd, London, UK, 6th edition, 1965.

16. Bergman RA, Afifi AK, Miyauchi Ret. Compendium of human anatomical variation: text, atlas and world literature. Baltimore, Urban and Schwarzenberg. 1988; 41: 282288.

17. Falk D, Zollikoferc CPE, Morimotoc N, de Leónc MSP. "Metopic suture of Taung (Australopithecus africanus) and its implications for hominin brain evolution". Proceedings of the National Academy of Sciences. 2012; 109: 8467-8470.

18. M. A. Sant'Ana Castilho, Oda YJ, Santana GDM. "Metopism in Adult Skulls from Southern Brazil". International Journal of Morphology. 2006; 24(1): 61-66.

19. Longaker. MT. Role of TGF-beta signaling in the regulation of programmed cranial suture fusion. J CraniofacSurg2001;12:389-90.

20. Faro C, Chaoui R, Wegrzyn P, Levaillant JM, Benoit B, Nicolaides KH. Metopic suture in fetuses with Apert syndrome at 22-27 weeks of gestation. Ultrasound Obstet Gynecol. 2006; 27:28-33.

21. Levine J, Bradley J, Roth D, McCarthy J, Longaker M. Studies in cranial suture biology: Regional dura mater determines overlying suture biology. Plast Reconstr Surg 1998;101:1441-7.

22. Breathnach AS. Frazer's anatomy of the human skeleton, 6thedn. London: Churchill Livingstone, 1965:178

23. Jit I, Banga N. Metopism in north-west population of India. J Anatomical Society of India. 1998; 37:45-60.

24. Zumpano PM, Carson BS, Marsh JL, Vanderkolk CA, Richtsmeier JT. Threedimensional morphological analysis ofisolated metopic synostosis. Anat Rec. 1999; 256: 177-188.

25. Hemalatha G, SubbaRao M. Persistent Metopic Suture in Adult Skulls of Andhra Pradesh. IOSR Journal of Dental and Medical Sciences.2016; Volume 15 (12): 04-06.

26. Bryce TH. Observations on Metopism.Journal of Anatomy. 1917; 51 (2): 153-166.

27. Del Sol M, Binvignat O, Bolini PD, Prates JC: Metopism in Brazilians. Rev Paul Med. 1989: 107:105-107.

Received on 18/12/2017 Revised on 00/00/0000 Accepted on 31/12/2017 